\title{
THE CCCTB ALLOCATION FORMULA GAME: \\ THE PERFORMANCE OF ECONOMIC SECTORS
}

\section{Kateřina Krchnivá, Danuše Nerudová*}

\begin{abstract}
The implementation of the Common Consolidated Corporate Tax Base (hereinafter CCCTB) in the European Union will probably have an impact on tax revenues of the concerned states since the distribution of the group tax base shall reflect the capacity to earn income by individual group members. This is secured by the employing of the allocation formula containing three factors that shall reflect the profit generating process of individual companies. The paper analyses the explanatory power of the proposed CCCTB formula on the data sample of group companies with a link to the Czech Republic - either parent or subsidiary company in the group covered in dataset is tax resident of the Czech Republic. The obtained results are evaluated on the level of individual economic sector with the aim to verify if the proposed CCCTB formula is the most suitable for them, where the sufficiency of the explanatory power of the allocation formula was indicated based on the assigned change of distributed profit to the respective economic sector.
\end{abstract}

Keywords: common consolidated corporate tax base, formula apportionment, NACE sectors, profit

JEL Classification: F23, H25, K34

\section{Introduction}

In 2001 the European Commission proposed a new approach for the taxation of multinational companies in the European Union (hereinafter as EU). This new approach is known as the Common Consolidated Corporate Tax Base (hereinafter as CCCTB). The CCCTB system was officially proposed by the publishing of the Draft Directive on the CCCTB on 16 March 2011. Based on the proposal the CCCTB system will be addressed to multinational groups of companies operating on the territory of the EU with a high degree of the economic cooperation, which will be derived from the held capital share and from the control interest of the parent company in its subsidiary. Moreover, based on the amendment of the CCCTB Directives from 25 October 2016, the system will be addressed only to multinational groups of companies whose consolidated turnover exceeds EUR 750 mil.

The CCCTB system should constitute a tax system with the common definition of the tax base giving to multinational companies a possibility to deal with their tax liabilities

* Kateřina Krchnivá, Faculty of Business and Economics, Mendel University, Brno, Czech Republic (k.krchniva@gmail.com);

Danuše Nerudová, Faculty of Business and Economics, Mendel University, Brno, Czech Republic (d.nerudova@seznam.cz).

The paper was funded by the Horizon 2020 Project No. 649439 called "Fair Tax". The financial support is gratefully acknowledged. 
at the international level, further a tax system decreasing tax burdens and tax compliance costs from their international business activities. Based on the relaunch of the CCCTB system from 17 June 2015 this system is mainly presented as an instrument against tax avoidance and tax frauds. The application of the system should eliminate the possibilities for aggressive tax planning arising in the current system of separate accounting (hereinafter as SA). The CCCTB system should replace the SA system with the system of formula apportionment (hereinafter as FA) based on the rules for the distribution of common consolidated group tax base that will be determined. The FA system is already applied for example by the United States of America (further as US), Canada, Switzerland or Germany. In Canada and the US the FA system is used for the allocation of corporate income tax on state or province level, in Switzerland on the level of cantons and in Germany it is applied for the distribution of the local business tax between municipalities.

On the contrary to the recently presented main contribution of the CCCTB system Nielsen et al. (2001) stated that in the structurally harmonized system, as the CCCTB system will be, the strategic tax planning and tax saving incentives may be stronger under the FA system (which is connected with the CCCTB) than in the SA system. They concluded that the relative strength of the tax spillovers is determined by two conditions: firstly, how costly the manipulation with transfer pricing for multinationals is and secondly, how high net profit they generate. According to Riedel and Runkel (2006), the FA system may establish a positive fiscal externality in the short-run, however, the long-run analysis shows that FA system initiates new problems and its capacity to solve shortcomings of the SA system is limited. Therefore, they stated that the FA system may serve an interim solution for the short run, however, in the long run the harmonization of the tax rates shall be obtained.

Under the FA system the companies do not distribute the income of an affiliated corporate group based on the geographic source, instead of this, a net income is calculated on the group level and is subsequently distributed among the locations where the business of a group company is carried out with the application of the special allocation formula (Gerard and Weiner, 2003). The FA system arranged for the EU is represented by the equal capacity to earn income approach indicating that the distribution of the group tax base reflects the group member's capacity to earn income. Under this approach the higher proportion of group tax base is distributed to a member, which has more profit-producing factors relative to others. In the other words, the tax jurisdiction where the group has more profit-producing factors in comparison with others should get larger proportion of the overall group tax base. According to Agundez-Garcia (2006), the fair apportioning rules have to assign corresponding share in tax base to the state with the reference to the factor(s) underlying income-producing activities within the states.

The implementation of the tax sharing system comprised by the CCCTB proposal may have significant effect on the tax revenues of the open post-transitional economy as the Czech Republic is. The aim of the paper is to verify the suitability of formulary apportionment for the distribution of the group tax base and on the example of the Czech Republic to research whether the CCCTB system will be able to reflect the profit generating process in each jurisdiction, where a member of the multinational corporation is settled. 
Further, we are searching for the evidence of the suitability of the CCCTB tax sharing system in individual economic sectors, where this suitability may be affected by the labour or capital intensity of the respective economic sector.

The FA systems introduced by the US and Canada use the formula which employs some combination of multinationals property, payroll and sales shares in the taxing jurisdictions. In the early 1980s McLure (1980) stated, that the FA system transforms the corporate income tax into tax on the apportionment factors. He suggested to move the internationally mobile capital out of the formula, since a tax on capital is fully passed into tax on the internationally immobile factors such as labour and land. Gordon and Wilson (1986) compared the FA system with the property taxation system in environmentally identical countries. They showed that under both types of taxes the harmful tax competition arises, however, the lower level of welfare is obtained if the FA system is applied.

In addition, Eggert and Schjelderup (2003) stated that FA is unable to fully tax a gross profit. This distortion is caused by the fact that apportionment enables companies to relocate activities to low-tax countries and thus reduce the average effective tax rate. Kolmar and Wagener (2007) declared that the tax competition is shaped by the spillover effect by which government's tax activities contribute to achieving of the objectives of other governments. They indicated that tax competition under the FA system leads to inefficiently high tax rates if a tax change of one country advantages the changes investment behaviour that go into the same direction. They concluded that in the FA system the tax competition may lead to low tax rates or to inefficiently high tax rates. Pethig and Wagener (2003) compared various methods of the FA with respect to their allocative features and strategic incentives. They stated that tax competition is sharper under the property or payroll apportionment than under the sales apportionment. Agundez-Garcia (2006) concluded that the tax competition under the FA system is very sensitive to the choice of the apportionment factors. Controversially, Anand and Sansing (2000) indicated based on the analysis of two-state equilibrium model that the aggregate social welfare is maximized when both states use the same formula, regardless to the fact which of formula is chosen. They also stated that the lack of uniformity of the FA across states can cause that more or less than 100 per cent of income is subject to the corporate income tax. According to them, this may be caused by different rules for computing of the formula factors or by different structure of the allocation formula. Such situation was demonstrated by simple sample, in which Anand and Sansing (2000) considered two states: Alabama employing three factor equally weighted formula, and Georgia applying the double-weighted sales formula. Considering the corporation having 50 per cent of its property, 40 per cent of its payroll, and 15 per cent of its sales in Alabama and remaining 50 per cent of its property, 60 per cent of its payroll, and 85 per cent of its sales in Georgia, then $(50$ per cent +40 per cent +15 per cent $) / 3$ $=35$ per cent of its income would be taxed in Alabama and $(50$ per cent +60 per cent + $2 *(85$ per cent $) / 4=70$ per cent would be taxed by Georgia.

On the other hand, Weiner (1999) argued that the exact definition of the formula is relatively unimportant since it does not have a great revenue impact on the concerned state. This was previously confirmed by the report of Willis Committee (1965) analysing the effect of the moving from the property-payroll formula to the property-payroll-sales 
by destination formula. The results of the analysis showed that the revenue generally fell in states with large manufacturing sector in comparison with states with a small manufacturing sector, the revenue impact was small.

Weiner (2005) indicated that the formula has to be internally consistent irrespective to the fact, whether the formula reflects the economic activity in the location. According to Tan (2010), the most appropriate formula may not be the one, which is most economically efficient, but that one, which is simple and politically feasible. Further, Agundez-Garcia (2006) declared that the choice and the weighting of the formula factor cannot be founded on the principles of scientific methodology, however, the factors should ultimately reflect the purpose of corporate taxation with respect to political preferences (whether it should remunerate producing or marketing states). She also argued that any formula can be justified on the grounds of subjective beliefs which factors are able to create economic value. As the result, she pointed out that only possibility how to determine the 'right' one formula is the conformity of affected states by the FA system.

After the long discussion the European Commission agreed on three-factor formula inspired by the Massachusetts formula incorporating labour, property and sales factors in their equal weight. The Massachusetts formula is employed in the United States of America since 1933, and currently is applied by 9 of 51 states of the federation ${ }^{1}$. The rest of states apply different structure of the allocation formula, most of them apply single-sales allocation formula (20 from 51 US states) following by the Massachusetts formula and double-weighted sales formula.

Labour, property and sales factors incorporated in the CCCTB allocation formula shall reflect both side of each economic transaction. The input factors (payroll and property) represent the supply side, while sales by destination factor (it means that profit on sales is taxed in the country where the delivery of the goods ends or where the ending recipient of a service is seated) represent the demand side. The property factor is generally considered as the most disturbing factor, since the capital or investments are the most mobile factors and these ones that companies may control over the location, whereas labour or sales by destination are assumed to be less mobile and controllable by companies (Agundez-Garcia, 2006). In this respect, Runkel and Schjelderup (2007) showed based on the model with two countries and a multinational firm having one subsidiary in both countries that it is always advantageous to include both mobile and immobile factors in the apportionment formula. They stated that provided a country changes the setting of the structure of allocation formula from the situation with labour as sole apportionment factor to the situation of combined payroll and capital factor, labour becomes in one country cheaper in comparison with the other. The effect of this change is the increase of demand for labour with rising wages and welfare in given country. The negative impact on capital formation in given country is zero degree at the margin.

The definition of assets factor in CCCTB allocation formula (hereinafter as CCCTB FA) is derived from the average amount of tangible fixed assets and will be assigned to its

1 Available at: http://www.taxadmin.org/assets/docs/Research/Rates/apport.pdf 
economic owner; the leased assets will be assigned to both - lessor and lessee. The labour factor will be computed as the combination of payroll costs and number of employees working for a respective group member. The definition of employee will follow the rules of a Member State on which territory his/her activity is performed. Payroll costs will cover of all payments that are deductible as expenses, including employees' benefits and social contributions. The combined composition of the labour factor should eliminate the problems with difference in the wage levels among the individual EU Member States. The sales factor will represent the sum of revenues from sales of goods and services decreased by warranty claims and rebates, where the revenues will be attributed to the state of dispatch or transport of goods and in the case of revenue from sales of services to the state on which territory the respective service is carried out.

The European Commission along the line of the formula apportionment applied in the United States of America and Canada proposed the special definition of allocation formula for finance and insurance activities, marine transport, gas and oil extraction activities. The arguments for special definition of the factors are that their current definition unsatisfactory reflects the profit generated in these industries. The special apportionment rules are adopted by some the US states for other industries like courier and package delivery services, telecommunication companies, film producers, professional sport teams and for fishing industry (Weiner, 2005). Similarly, with the US formula apportionment system, the European Commission proposed the security clause allowing to the tax payer to apply different setting of the allocation formula provided that the proposed formula is inappropriate to explain the generated profit.

\section{Data and Methodology}

The paper is aimed at the research of the suitability of the CCCTB FA for the distribution of the tax base of a group company. As the alternative of the CCCTB FA there are considered formulas which are commonly used in the United States of America (hereinafter US FA) and Canada (hereinafter Canadian FA). The analysis is performed from the perspective of the Czech Republic, since only the data of the multinational companies with any link to the Czech Republic are employed in the analysis (i.e. either subsidiary or parent company is tax resident in the Czech Republic). The suitability of the CCCTB FA is measured by the change in the distributed share on overall tax base of the analysed group companies assigned to separate economics sectors classified by the NACE codes. In details, we compare the share in the overall tax base of the analysed dataset assigned to an individual economic sector in the current system of SA with the share, which would be assigned to the respective economic sector provided that the consolidated tax base would be distributed according to the CCCTB FA, or according to the US FA or Canadian FA. This analysis step is further accompanied by the verification of the explanatory power of considered formulas, which is evaluated based on the comparison of the coefficients of determination arranged by multiple regression models. At the end both analysis steps are evaluated together under the hypothesis, that the explanatory power of the CCCTB FA or of the US and Canadian FA may be considered as sufficient, if the change in the distributed share to the individual 
economic sector does not significantly differ. As the measurement of the significance was the rate of 0.05 per cent change in profit chosen.

The structure of the proposed allocation formula by the Draft Directive on the CCCTB is presented by below stated equation:

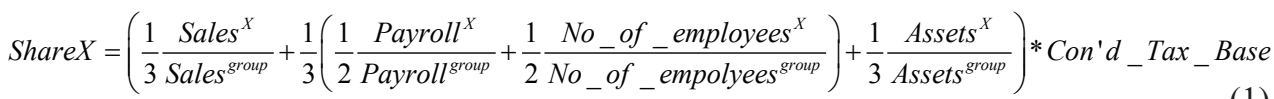

where a share of group company member $\mathrm{X}$ in the common consolidated corporate tax base is determined as its share in the overall volume of sales, tangible fixed assets and labour, which is derived from the combination of payroll costs and number of employees.

The secondary data for the analysis were gained from Amadeus database, namely from its update No. 2442 from 22 January 2015. All data refer to the period of the year 2013. Only the data of group companies fulfilling two-tier eligibility test determined by the Article No. 54 of the Draft Directive on the CCCTB were taken into consideration. The two-tier eligibility test determines that the CCCTB system will be addressed only to group companies with high level of economic cooperation, which is indicated by the participation of a parent company in its subsidiary by the ownership threshold higher of 75 per cent and by the criterion of control with requirement of higher than 50 per cent proportion on voting rights and higher than 75 per cent share on rights giving the entitlement to profit.

As stated above, the analysis was performed from the perspective of the Czech Republic, therefore the considered group companies had to have a link the Czech Republic. The data of Czech parent companies and their eligible subsidiaries resident in the EU were included into studied data sample. In addition, also the data of parent companies resident elsewhere in the EU and their eligible subsidiaries seated in the EU were also taken into consideration, however, these group companies had to fulfil the additional criterion requiring that at least one of the eligible subsidiaries has to be resident in the Czech Republic.

Except for data indicating the ownership structure also the financial data of all companies necessary for the calculation of the distributed share in overall tax base were gained from the Amadeus database. These were: an information on the profit/ loss before taxation (referred as $P L$ ), which was considered as a proxy of the tax base, information on the amount of tangible fixed assets (referred as TFA), which represents the assets factor in the allocation formula (1), amount of operating turnover representing the sales factor (further as $O P T$ ), information on amount of payroll costs (referred as $C o E$ ) accompanied by number of employees (referred as $N o E$ ), which together serve the labour factor of allocation formula. All financial data were converted in thousands of euros.

In addition to financial data, also the information on the country of residency of an individual company and the sector of its economic activity were obtained for data sample. Furthermore, all companies included into studied data sample have published information on profit/loss before taxation and volume of tangible fixed assets in 2013, which were necessary for the computation of missing values of other variables.

The total volume of the sample consisted of 11,474 companies, covering 1,641 parent companies and 9,833 subsidiaries resident in 28 EU Member States. The structure of the sample can be seen in the following table (Table 1). 
Table 1 | Structure of the Sample

\begin{tabular}{|c|c|c|c|c|}
\hline $\begin{array}{l}\text { Country } \\
\text { code }\end{array}$ & Country name & $\begin{array}{l}\text { Number of parent } \\
\text { companies }\end{array}$ & $\begin{array}{c}\text { Number of subsidiary } \\
\text { companies }\end{array}$ & $\begin{array}{l}\text { Total number } \\
\text { of companies }\end{array}$ \\
\hline АT & Austria & 48 & 255 & 303 \\
\hline BE & Belgium & 31 & 504 & 535 \\
\hline BG & Bulgaria & 1 & 0 & 1 \\
\hline CY & Cyprus & 1 & 1 & 2 \\
\hline$C Z$ & Czech Republic & 1,097 & 2,442 & 3,539 \\
\hline DE & Germany & 86 & 278 & 364 \\
\hline DK & Denmark & 15 & 132 & 147 \\
\hline EE & Estonia & 0 & 71 & 71 \\
\hline ES & Spain & 13 & 554 & 567 \\
\hline $\mathbf{F I}$ & Finland & 18 & 215 & 233 \\
\hline FR & France & 46 & 1,213 & 1,259 \\
\hline UK & United Kingdom & 68 & 1,287 & 1,355 \\
\hline GR & Greece & 1 & 82 & 83 \\
\hline HR & Croatia & 2 & 0 & 2 \\
\hline HU & Hungary & 3 & 285 & 288 \\
\hline IE & Ireland & 5 & 41 & 46 \\
\hline IT & Italy & 41 & 749 & 790 \\
\hline LT & Latvia & 0 & 20 & 20 \\
\hline LU & Luxembourg & 0 & 21 & 21 \\
\hline LV & Lithuania & 1 & 69 & 70 \\
\hline MT & Malta & 1 & 1 & 2 \\
\hline NL & Netherlands & 57 & 367 & 424 \\
\hline PL & Poland & 21 & 319 & 340 \\
\hline PT & Portugal & 1 & 132 & 133 \\
\hline RO & Romania & 1 & 0 & 1 \\
\hline SE & Sweden & 32 & 318 & 350 \\
\hline SI & Slovenia & 7 & 79 & 86 \\
\hline SK & Slovakia & 44 & 398 & 442 \\
\hline \multicolumn{2}{|l|}{ Total } & 1,641 & 9,833 & 11,474 \\
\hline
\end{tabular}

Source: Amadeus database, Version 2442, 15 January 2015, adjusted by authors. 
Although the Amadeus database represents the unique instrument containing the information on around 21 million companies across Europe, which covers financial indicators as well as ownership structures of these companies, not all private company information is always available in the database. This is mainly caused by delays in the data processing by the national administrators or this information is not published by these companies. Despite to this fact, the Amadeus database represents the powerful and special tool for not only research of companies' data, but also for the tax administrators, and it cannot be substituted by collecting of primary data.

With respect to above mentioned and with the aim to secure the maximum coverage of the studied data sample we have performed the imputation of missing values. In order to perform the imputation of the missing values the studied data sample had to fulfill additional requirement indicating that all considered companies had to have published the information on the volume of tangible fixed assets, the county of residency and about the sector of economic activity indicated by NACE codes. The missing values of factor variables (OPT, TFA, NoE and $C o E$ ) for the studied data sample of 11,474 companies were imputed in case of operating turnover (OPT) for 661 companies (the missing values represent 5.76 per cent share of studied data sample), in case of number of employees ( $N o E$ ) for 3,544 companies (the missing values represent 30.89 per cent share of studied data sample) and in case of cost on employees $(C o E)$ for 3,336 companies (the missing values represent 29.07 per cent share of studied data sample). In the line with the researched strategy of the data sample there were no missing values for variable tangible fixed assets (TFA).

Based on above mentioned, it is evident that the exclusion of the companies with any missing variable would have a significant impact on the extent of the studied data sample and subsequently on results of the performed research. Further, it is necessary to consider the fact that without the imputation of missing values the complexity and the generalization of such research cannot be ensured.

For the imputation of missing values was applied the imputation method using the ratios of the factor to assets which was evaluated as the most suitable method which would not significantly distort the allocation of the group tax base between the EU Member States by Nerudová and Solilová (2014).

As stated above the imputation of missing values there was performed in similar way as by Cline et al. (2010), Nerudová and Solilová (2014) or Nerudová et al. (2015). This imputation method is based on the predefined relationships between factor variables $(O P T$, $T F A, N o E$ and $C o E$ ) in the allocation formula. Under these relationships, it is supposed that the volume of operating turnover $(O P T)$ and number of employees $(N o E)$ may be derived from the value of tangible fixed assets (TFA), while the volume of costs on employees $(\mathrm{CoE})$ may be acquired from number of employees. If the level of economic development differs between the Western European countries and the Eastern European countries, the ancillary dataset was divided into two parts. Firsts one contained only data on companies resident in the first fifteen EU Member States (EU15) ${ }^{2}$, while the second one consisted from data

2 Austria, Belgium, Germany, Denmark, Spain, Finland, France, the United Kingdom, Greece, Ireland, Italy, Luxembourg, the Netherlands, Portugal, Sweden. 
of companies seated in the countries enlarging the EU since 2004 (EU13) ${ }^{3}$. In the next step, the EU15 and the EU13 sub-data sample were divided according to NACE sectors with the aim to get the basis for the imputation of missing values of an individual company with the characteristics typical for the individual economic sectors.

For the calculation of missing values there was used the ancillary dataset obtained from the Amadeus database. The ancillary dataset consisted from the data of group companies eligible for the CCCTB system within the whole EU. The requirements on the data covered by the ancillary dataset were the same as for the studied dataset. The ancillary dataset consisted of 153,012 companies resident in the EU, where 48,101 were parent companies and the rest of 104,919 companies were their eligible subsidiaries. For the imputation of missing values of sales factor were available 142,031 values of operating turnover in ancillary dataset. Missing values of assets factor were imputed based on 152,363 accessible values. Labour factor of companies in the studied data sample (see Table 1) were imputed based on 106,213 available values of payroll costs and 93,583 values of number of employees.

As was already stated above, the missing values were calculated based on the predefined relationships between factor variables. Firstly, the imputation coefficients for every variable in every NACE sector and resident in the Western or Eastern part of the EU were calculated.

The imputation coefficients for every factor variable were calculated according to below stated relations:

$$
\begin{aligned}
& O P T_{-} \text {imputation_coefficient }=\frac{\text { average } \_P P T}{\text { average_TFA }} \\
& N o E_{\text {_imputation_coefficient }}=\frac{\text { average } \_N o E}{\text { average_TFA }} \\
& C o E_{-} \text {imputation_coefficient }=\frac{\text { average } \_ \text {CoE }}{\text { average } \_ \text {NoE }}
\end{aligned}
$$

In line with these relations, the imputation coefficients for sales factor (2) were calculated based on the ratio of average value of operating turnover to average value of tangible fixed assets of companies with both published values. The imputation coefficients for number of employees (3) were calculated as the ratio of average value of number of employees to average value of tangible fixed assets of companies with both available values. And similarly, the imputation coefficients for payroll costs (4) were calculated as the ratio of average payroll costs to average number of employees of all companies with known values of both variables. It is necessary to mention, that there was no necessity to calculate imputation coefficient for assets factor, since the data search strategy required that all the companies had published the information on the value of tangible fixed assets in their financial statements.

The calculated imputation coefficients according to the above indicated relations were used for the computation of missing values based on the below equations:

3 Bulgaria, Cyprus, the Czech Republic, Estonia, Croatia, Hungary, Latvia, Lithuania, Malta, Poland, Romania, Slovenia, Slovakia. 


$$
\begin{aligned}
& M I S S I N G_{-} O P T=O P T \_ \text {imputation_coefficient } * \text { known_TFA } \\
& M I S S I N G_{-} N o E=N o E \_ \text {imputation_coefficient } * \text { known_TFA } \\
& M I S S I N G \_C O E=C O E \_ \text {imputation_coefficient } * \text { known_NoE }
\end{aligned}
$$

where the missing value of any variable $(O P T, N o E$ or $C o E)$ was calculated as the multiple of imputation coefficient to known/imputed value of other factor variable.

After the imputation of missing values, the calculation of the distribution of the overall group tax base in the current system of separate accounting and in the CCCTB system was performed. Furthermore, in line with the aim of the paper, the hypothetical calculation of the distribution of the tax base under the US Massachusetts and the Canadian FA was performed. This analysis step was performed with the aim to identify the differences in the distribution of the overall tax base of the studied data sample under the application of different formulas apportionment. Further with the aim to compare the distributed shares assigned to individual economic sectors in current SA system and formula apportionment systems, where the distributed share is influenced by the proportion of individual factors in the formula and its presence on accounts of an individual company.

The distribution of the group tax base in the current system was executed with the application of the rules for the computation of the group tax base relevant for 2013. Three main groups of countries applying the similar approach to group taxation were identified within the EU. First group of countries represents these ones, which do not apply any group taxation scheme, these are: the Czech Republic, Croatia, Estonia, Finland, Greece, Hungary, Slovakia, Slovenia and Romania. The next group of countries covers those countries in which the tax loss offsetting scheme within the companies in the same group may be applied, these countries are: Ireland, Latvia, Sweden and the United Kingdom. And lastly, the group of countries in which tax consolidation scheme is applicable were identified. These are: Austria, Denmark, France, Germany, Italy, Lithuania, Luxembourg, Malta, the Netherlands, Poland, Portugal and Spain. It is necessary to mention that in case that companies seated in the first group of countries, i.e. in those countries which do not apply any group taxation scheme, ran the loss - the tax base was counted to be zero.

Further, the distribution of the tax base under the CCCTB system was performed. Under this system net income of the group companies is distributed among the individual members based on the allocation formula (1). The calculation of the net income means that under the CCCTB system the tax loss offsetting scheme is applied. In accordance with the objective of the paper also the calculations of the tax base in the US and the Canadian FA were performed. Under the US FA the distribution of the group tax base was carried out according to three factor formula comprising sales, assets and labour factors. While under the Canadian FA the distribution of the group tax base according formula with two factors, namely labour and sales, was performed. Under both additional formulas the loss offsetting scheme was applied as well. The structure of these formulas can be seen in below stated equations: 
US Massachusetts formula:

$$
\text { ShareX }=\left(\frac{1}{3} \frac{\text { Sales }^{x}}{\text { Sales }_{\text {group }}}+\frac{1}{3} \frac{\text { Payroll }^{X}}{\text { Payroll }_{\text {group }}}+\frac{1}{3} \frac{\text { Assets }^{x}}{\text { Assets }^{\text {group }}}\right) * \text { Con'd_Tax_Base }
$$

Canadian formula:

$$
\text { ShareX }=\left(\frac{1}{2} \frac{\text { Payroll }^{X}}{\text { Payroll }_{\text {group }}}+\frac{1}{2} \frac{\text { Sales }^{x}}{\text { Sales }^{\text {group }}}\right) * \text { Con'd }_{-} \text {Tax_Base }
$$

This research phase was accompanied by further research part aimed at the verification of the explanatory power of the considered allocation formulas with special intention to examine explanatory power of the formulas in the separated economic sectors. The aim of this phase of the research was to verify the ability of the formula, more specifically by their factors, to significantly explain the profit generating process of the considered companies. Afterwards, both researched steps were put together and the suitability of the formulas were examined from the perspective of the change in the distributed share on overall tax base to individual economic sectors. The aim of the combination of both research steps was to evaluate if the identified explanatory power of the allocation formula in the individual economic sectors is sufficient. The evaluation of the explanatory power was performed under the hypothesis that the indicated explanatory power of the analysed formulas is sufficient, provided the change in the distributed share on overall tax base to individual economics sector is lower of 0.05 per cent change in the distributed share.

The analysis of the explanatory power of allocation formula was based on the comparison of the coefficients of determination indicating the proportion of explained variability of examined regression model. The similar study was previously performed by Roggeman et al. (2012), Krchnivá and Nerudová (2015) or Krchnivá (2015). Roggeman et al. (2012) researched whether the factors entering the CCCTB formula may be considered as a main profit generating factors based on firm-level data from Amadeus database for the European manufacturing and service sector in the year $2008^{4}$. Their results showed that the best performing formula is the three factor formula including sales, tangible assets and costs on employees, which are able to significantly explain 28 per cent of the variation in profit between the companies. Krchnivá (2015) analysed the variety of the designs of the CCCTB allocation formula on the data of the Czech individual companies in 2012. She showed that the CCCTB formula factors are able to explain almost 35 per cent of the variability in profitability of companies, however, the composition of assets factor as the volume of total assets may have a larger impact on the generation of profit/loss since this factor reflects both fixed assets and financial assets, which in certain types of industry sectors could constitute an important indicator

$\overline{4 \quad \text { Manufacturing }}$ companies: NACE codes 15-36 and services: NACE Codes 50-74 and 92. 
of profitability. Subsequently, Krchnivá and Nerudová (2015) analysed on the same data sample the explanatory power of the CCCTB formula in the individual economic sectors. They showed that in the most common economic sector in the Czech Republic (NACE sector G - Whole sale and retail trade; Repair of motor vehicles and motorcycles) the explanatory power reaches up to 30.33 per cent, respectively up to 26.33 per cent based on the results of restricted regression model.

Since multivariate regression models with different number of independent variables were considered in the analysis, the evaluation of the explained variability by the models was operated based on the comparison of the adjusted coefficients of determination, which are able to eliminate possible distortion caused by involving of different number of independent variables.

The following equation presents the structure of analysed multivariate regression models:

$$
P L_{n}=\beta_{0}+\beta_{1} C o E_{n}+\beta_{2} N o E_{n}+\beta_{3} T F A_{n}+\beta_{4} O P T_{n}
$$

where the $P L$ represents profit/loss before taxes as the dependent variable which is explained by different number of independent variables. In case of the CCCTB FA there were considered four independent variables, these were payroll costs $(C o E)$, volume of tangible fixed assets (TFA) and operating turnover $(O P T)$ and number of employees $(N o E)$. Under the examination of the US FA, three independent variables were considered, namely $O P T, T F A$ and $C o E$. Lastly for the Canadian FA two independent variables were employed, namely $O P T$ and $C O E$.

The positive linear links between dependent and independent variables were assumed. Except for unrestricted regression models, also restricted regression models were researched. In the restricted regression models the independent variables are supposed to be equally weighted and therefore be able to better reflect the structure of allocation formula. The parameters of the examined multivariate regression models were estimated by the Ordinary Last Squares method. All proposed regression models were tested by $F$-test verifying the statistical significance of studied regression model. All observed regression models were statistically significant at 1 per cent significance level. In addition, all obtained adjusted coefficients of determination were tested for statistical significance. There were all statistically significant at 1 per cent significance level, if not stated differently.

The ancillary dataset was employed in the research of the explanatory power of allocation formulas with the aim to secure the ability of the generalization of obtained results. However, some adjustments of the dataset needed to be done. At the first stage, only the companies with the available information on all formula factors were selected. Secondly, extreme values under of 1 per cent and above of 99 per cent percentile were eliminated. Finally, the dataset was further divided into sub-datasets according to the economics sectors classified by the NACE codes. The structure of the dataset for the analysis of the explanatory power can be observed in Table 2 . 
Table 2 | Structure of Dataset for the Research of Formula Factors Explanatory Power

\begin{tabular}{|c|c|c|c|c|}
\hline Code & Description & $\begin{array}{l}\text { Details (first } \\
\text { two digits) }\end{array}$ & $\begin{array}{l}\text { Number } \\
\text { of subjects }\end{array}$ & $\begin{array}{l}\text { percentage } \\
\text { proportion }\end{array}$ \\
\hline A & agriculture, forestry and fishing & $01-03$ & 896 & 1.14 \\
\hline B & mining and quarrying & $05-09$ & 534 & 0.68 \\
\hline C & manufacturing & $10-33$ & 17,963 & 22.87 \\
\hline D & $\begin{array}{l}\text { electricity, gas, steam and air } \\
\text { conditioning supply }\end{array}$ & 35 & 758 & 0.96 \\
\hline $\mathbf{E}$ & $\begin{array}{l}\text { water supply; sewerage, waste } \\
\text { management and remediation activities }\end{array}$ & $36-39$ & 783 & 1.00 \\
\hline $\mathbf{F}$ & construction & $41-43$ & 5,779 & 7.36 \\
\hline G & $\begin{array}{l}\text { wholesale and retail trade; repair } \\
\text { of motor vehicles and motorcycles }\end{array}$ & $45-47$ & 17,358 & 22.10 \\
\hline $\mathbf{H}$ & transportation and storage & $49-53$ & 3,770 & 4.80 \\
\hline $\mathbf{I}$ & $\begin{array}{l}\text { accommodation and food service } \\
\text { activities }\end{array}$ & $55-56$ & 2,590 & 3.30 \\
\hline J & information and communication & $58-63$ & 4,786 & 6.09 \\
\hline $\mathbf{K}$ & financial and insurance activities & $64-66$ & 4,049 & 5.15 \\
\hline $\mathbf{L}$ & real estate activities & 68 & 2,830 & 3.60 \\
\hline $\mathbf{M}$ & $\begin{array}{l}\text { professional, scientific and technical } \\
\text { activities }\end{array}$ & $69-75$ & 8,043 & 10.24 \\
\hline $\mathbf{N}$ & $\begin{array}{l}\text { administrative and support service } \\
\text { activities }\end{array}$ & $77-82$ & 4,583 & 5.83 \\
\hline $\mathbf{0}$ & $\begin{array}{l}\text { public administration and defence; } \\
\text { compulsory social security }\end{array}$ & 84 & 34 & 0.04 \\
\hline $\mathbf{P}$ & education & 85 & 471 & 0.60 \\
\hline $\mathbf{Q}$ & human health and social work activities & $86-88$ & 1,693 & 2.16 \\
\hline $\mathbf{R}$ & arts, entertainment and recreation & $90-93$ & 902 & 1.15 \\
\hline $\mathbf{S}$ & other service activities & $94-96$ & 727 & 0.93 \\
\hline $\mathbf{T}$ & $\begin{array}{l}\text { activities of households as employers; } \\
\text { u0ndifferentiated goods- and services- } \\
\text { producing activities of households for } \\
\text { own use }\end{array}$ & $97-98$ & 4 & 0.01 \\
\hline $\mathbf{U}$ & $\begin{array}{l}\text { activities of extraterritorial organisations } \\
\text { and bodies }\end{array}$ & 99 & 6 & 0.01 \\
\hline & & & 78,559 & 100.00 \\
\hline
\end{tabular}

Source: Amadeus database, version 2442, 15 January 2015, adjusted by authors. 


\section{Results and Discussion}

The paper deals with the research of the suitability of the CCCTB allocation formula for the distribution of the group tax base on the example of the Czech Republic with the special focus on the examination of the suitability of the formula in separate economic sectors classified by the NACE codes. As the alternative of the CCCTB allocation formula were considered the US Massachusetts formula and Canadian allocation formula. The perspective of the Czech Republic was ensured by the fact that studied data sample contains data of group companies with a link to the Czech Republic, i.e. either subsidiary or parent company is tax resident of the Czech Republic.

The analysis was performed based on two individual research steps which were further evaluated both together with the aim to evaluate the sufficiency of the explanatory power of formulas in individual economic sectors. Firstly, the explanatory power of the considered formulas was analysed based on the examination of the adjusted coefficients of determination of proposed multivariate regression models (10). As mentioned earlier, both unrestricted as well as restricted multivariate regression models were examined. The restricted regression models assume that the impact of the independent variables on the dependent variable is equal, which may better indicate the structure of the proposed allocation formulas. The results of the first research step are stated in the table below (Table 3).

It is obvious from the Table 3 that the explanatory power of the CCCTB FA for companies operating in all economics sectors amounts to 27.88 per cent in case of unrestricted regression model, or to 26.32 per cent in case of the restricted regression model. The proportion of explained variability by the CCCTB FA is particularly equal with results for the US formula, and almost by 1 per cent lower than the proportion of explained variability by the Canadian FA. For the biggest economics sectors in the analysed dataset, i.e. NACE sector $\mathrm{C}$ and $\mathrm{NACE}$ sector $\mathrm{G}$, the proportion of explained variability amounts to 40.96 per cent, or to 29.56 per cent, in case of the CCCTB unrestricted regression model, and to 39.90 per cent, or to 26.14 per cent, in case of the restricted regression model.

Further, Table 3 shows that the highest proportion of variability in the generation of profit is explained by all analysed formulas, namely by the CCCTB FA, the US FA and the Canadian FA, for NACE sectors O, P, Q, S and C. On the other side, the lowest share of variability in profit generation is explained by analysed formulas for NACE sectors $\mathrm{K}, \mathrm{R}, \mathrm{I}$ and $\mathrm{D}$. The obtained results for NACE sector $\mathrm{K}$ are justifiable for the arrangement of the special definition of allocation formula for finance and insurance business activities. With the reference to the results for NACE sectors R and I may be arranged the incorporation of the highest proportion of labour and sales factors, since the profit generated by food, accommodation services and entertainment industries is probably more influence by volume of consumers' demand and the individuals providing these services than by machinery equipment represented in the assets factor. 


\begin{tabular}{|c|c|c|c|c|c|c|c|c|c|c|c|c|c|c|c|c|c|c|c|c|c|c|c|c|c|}
\hline \multirow{4}{*}{ 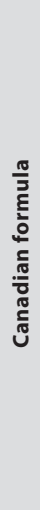 } & \multirow{2}{*}{ 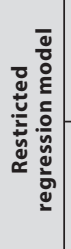 } & 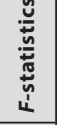 & 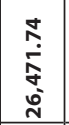 & $\begin{array}{l}\infty \\
m \\
\stackrel{\rho}{m} \\
m\end{array}$ & \begin{tabular}{|l}
$\hat{f}$ \\
$\stackrel{D}{~}$ \\
$\tilde{N}$
\end{tabular} & 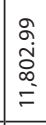 & $\begin{array}{l}\bar{\sigma} \\
\dot{\alpha} \\
i\end{array}$ & 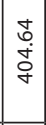 & 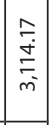 & $\begin{array}{l}\hat{n} \\
\text { S. } \\
\text { مू }\end{array}$ & 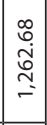 & 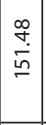 & 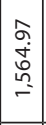 & $\begin{array}{l}\hat{m} \\
0 \\
0 \\
0\end{array}$ & \begin{tabular}{|c|}
0 \\
0 \\
$\infty$ \\
$\infty$ \\
$\infty$ \\
\end{tabular} & $\mid \begin{array}{l}0 \\
0 \\
\\
0 \\
i \\
i\end{array}$ & $\begin{array}{c}\stackrel{1}{0} \\
\dot{0} \\
0 \\
0 \\
\stackrel{-}{-} \\
\end{array}$ & $\underset{\stackrel{q}{\sim}}{\stackrel{q}{*}}$ & 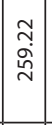 & $\begin{array}{l}\stackrel{0}{\grave{d}} \\
\underset{\sim}{\sim} \\
\sim\end{array}$ & 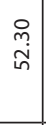 & 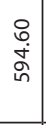 & 1 & 1 & 1 \\
\hline & & $\underset{\check{\pi}}{\stackrel{\check{\tau}}{\tau}}$ & 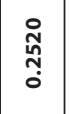 & $\begin{array}{l}\overline{\widehat{\sigma}} \\
\text { ָ̦ }\end{array}$ & 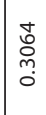 & $\begin{array}{l}n \\
\stackrel{0}{0} \\
\text { m. } \\
0\end{array}$ & $\mid \begin{array}{l}\pi \\
\tilde{D} \\
0 \\
0\end{array}$ & $\mid \begin{array}{c}0 \\
0 \\
0 \\
0 \\
0\end{array}$ & $\mid \begin{array}{c}\bar{\delta} \\
\hat{n} \\
0 \\
o \\
o\end{array}$ & 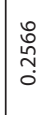 & \begin{tabular}{|l|}
$\stackrel{0}{0}$ \\
$\stackrel{0}{n}$ \\
0 \\
\end{tabular} & 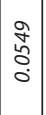 & 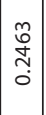 & $\frac{\bar{a}}{\bar{d}}$ & $\mid \begin{array}{l}0 \\
\stackrel{0}{0} \\
\sim \\
0 \\
0\end{array}$ & $\mid$\begin{tabular}{|l}
$n$ \\
0 \\
$\grave{i}$ \\
0
\end{tabular} & $\mid \bar{\sigma}$ & 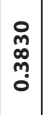 & 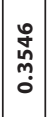 & $\begin{array}{l}\infty \\
\hat{0} \\
\\
0\end{array}$ & 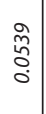 & 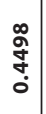 & 1 & 1 & 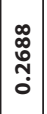 \\
\hline & \multirow{2}{*}{ 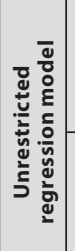 } & 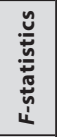 & 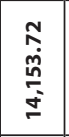 & 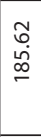 & $\frac{\sigma}{\sigma}$ & $\begin{array}{l}2 \\
0 \\
\infty \\
0 \\
0 \\
0\end{array}$ & $\begin{array}{c}\hat{m} \\
\dot{o} \\
\dot{q}\end{array}$ & $\begin{array}{l}\stackrel{n}{0} \\
\infty \\
\stackrel{0}{0}\end{array}$ & \begin{tabular}{|l|}
0 \\
0 \\
0 \\
0 \\
0 \\
\hdashline \\
-
\end{tabular} & 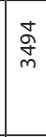 & \begin{tabular}{|l|}
$\hat{\omega}$ \\
0 \\
0 \\
$\hat{\sigma}$ \\
\end{tabular} & $\stackrel{m}{\infty}$ & $\mid \begin{array}{c}\hat{n} \\
\tilde{n} \\
\stackrel{n}{n}\end{array}$ & 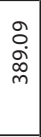 & 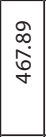 & \begin{tabular}{|c|}
0 \\
0 \\
$\dot{+}$ \\
0 \\
\hdashline \\
- \\
\end{tabular} & 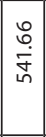 & 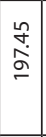 & 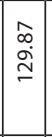 & 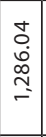 & $\begin{array}{l}\hat{n} \\
\dot{\rho} \\
i n\end{array}$ & $\begin{array}{l}\bar{\sigma} \\
\grave{\vdots} \\
\grave{N}\end{array}$ & 1 & 1 & 1 \\
\hline & & $\underset{\check{\pi}}{\stackrel{\check{\sigma}}{\bar{\tau}}}$ & $\begin{array}{l}\text { gे } \\
\stackrel{\text { N̦ }}{0}\end{array}$ & 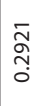 & $\begin{array}{c}\text { th } \\
\stackrel{0}{0} \\
0\end{array}$ & $\begin{array}{l}0 \\
0 \\
0 \\
0 \\
0 \\
0\end{array}$ & 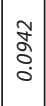 & $\begin{array}{l}n \\
0 \\
0 \\
m \\
0 \\
0\end{array}$ & 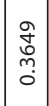 & \begin{tabular}{|c|}
$\stackrel{P}{0}$ \\
$\stackrel{\infty}{0}$ \\
$\stackrel{0}{0}$
\end{tabular} & $\begin{array}{c}\tilde{N} \\
\stackrel{N}{0} \\
0\end{array}$ & 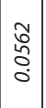 & 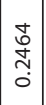 & $\begin{array}{l}0 \\
0 \\
\circ \\
0\end{array}$ & $\mid \begin{array}{c}0 \\
\infty \\
\stackrel{D}{0} \\
0\end{array}$ & 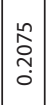 & 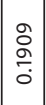 & 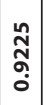 & $\begin{array}{c}\mathcal{Y} \\
\hat{w} \\
\tilde{o} \\
0\end{array}$ & $\begin{array}{l}0 \\
\stackrel{\tilde{m}}{0} \\
0 \\
0 \\
\dot{0}\end{array}$ & 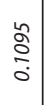 & $\begin{array}{l}\bar{\sigma} \\
\dot{g} \\
\dot{0}\end{array}$ & 1 & 1 & 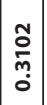 \\
\hline \multirow{4}{*}{ 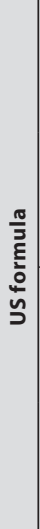 } & \multirow{2}{*}{ 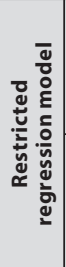 } & 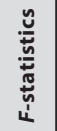 & 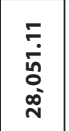 & $\begin{array}{l}0 \\
\infty \\
\tilde{j} \\
\tilde{\gamma}\end{array}$ & 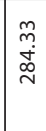 & 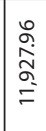 & 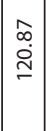 & 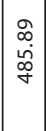 & $\mid \begin{array}{l}\tilde{n} \\
\tilde{m} \\
\tilde{m} \\
m\end{array}$ & 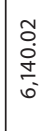 & \begin{tabular}{|l|}
$\stackrel{2}{\sim}$ \\
$\stackrel{\sim}{\tilde{n}}$ \\
$\stackrel{-}{-}$
\end{tabular} & $\begin{array}{l}\hat{0} \\
\dot{J} \\
\dot{J}\end{array}$ & 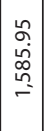 & $\begin{array}{l}\bar{f} \\
\dot{q} \\
\dot{b}\end{array}$ & \begin{tabular}{|l|} 
\\
\\
ڤે \\
\end{tabular} & $\mid \begin{array}{l}0 \\
0 \\
0 \\
\vdots \\
0 \\
i\end{array}$ & 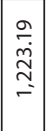 & $\begin{array}{l}\stackrel{0}{\sim} \\
\underset{\sim}{\sim}\end{array}$ & $\begin{array}{l}\tilde{\sigma} \\
\hat{\alpha} \\
\tilde{j}\end{array}$ & 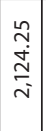 & $\begin{array}{l}0 \\
\stackrel{0}{0} \\
\stackrel{1}{\wedge}\end{array}$ & $\begin{array}{l}\hat{N} \\
\hat{i} \\
\hat{\sigma}\end{array}$ & 1 & 1 & 1 \\
\hline & & $\underset{\tilde{\sigma}}{\tilde{\tau}}$ & $\begin{array}{l}\overline{\hat{0}} \\
\stackrel{0}{0} \\
0\end{array}$ & 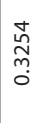 & 京 & $\begin{array}{l}\text { ̊. } \\
\text { ஸे } \\
\text { o. }\end{array}$ & $\mid$\begin{tabular}{|c|}
0 \\
$\stackrel{0}{0}$ \\
$\dot{0}$
\end{tabular} & $\mid \begin{array}{c}\tilde{o} \\
\infty \\
\tilde{o} \\
o\end{array}$ & $\begin{array}{c}\stackrel{\infty}{0} \\
\stackrel{m}{0} \\
o\end{array}$ & $\begin{array}{l}\frac{m}{\sigma} \\
\stackrel{2}{0} \\
0\end{array}$ & \begin{tabular}{|c|}
$\infty$ \\
$\stackrel{0}{0}$ \\
\\
0
\end{tabular} & 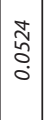 & 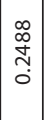 & $\stackrel{\substack{m \\
0}}{0}$ & $\mid \begin{array}{l}m \\
\stackrel{\alpha}{0} \\
\frac{0}{0}\end{array}$ & 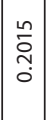 & $\begin{array}{l}\stackrel{0}{0} \\
\grave{j} \\
0\end{array}$ & 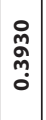 & $\mid \begin{array}{l}0 \\
\hat{q} \\
0 \\
0\end{array}$ & 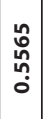 & $\begin{array}{l}\bar{o} \\
\infty \\
0 \\
0\end{array}$ & 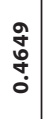 & 1 & 1 & 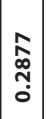 \\
\hline & \multirow{2}{*}{ 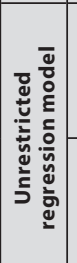 } & 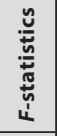 & 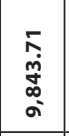 & $\begin{array}{l}\stackrel{\infty}{\sim} \\
\stackrel{n}{n}\end{array}$ & $\begin{array}{l}\text { กै. } \\
\text { ूँ }\end{array}$ & $\begin{array}{l}n \\
\hat{\infty} \\
\dot{\infty} \\
\infty \\
o \\
\dot{+}\end{array}$ & $\mid \begin{array}{l}\bar{\alpha} \\
\dot{\rho} \\
\stackrel{p}{0}\end{array}$ & $\mid$\begin{tabular}{l}
$m$ \\
\multirow{o}{0}{} \\
$o$ \\
$o$
\end{tabular} & 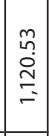 & $\begin{array}{l}\stackrel{0}{\mathfrak{m}} \\
\stackrel{m}{m} \\
\sim\end{array}$ & $\mid \begin{array}{l}\tilde{\sigma} \\
\dot{\gamma} \\
\tilde{y}\end{array}$ & $\begin{array}{l}\infty \\
\stackrel{\infty}{n} \\
i n\end{array}$ & $\mid \begin{array}{c}\bar{N} \\
\tilde{N} \\
\tilde{n}\end{array}$ & 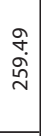 & $\begin{array}{l}q \\
\stackrel{q}{m} \\
m \\
\end{array}$ & \begin{tabular}{|l|l}
$\infty$ \\
$\stackrel{2}{2}$ \\
$\stackrel{2}{2}$
\end{tabular} & $\begin{array}{c}\bar{\infty} \\
\dot{\bar{\sigma}} \\
\overline{\bar{\sigma}}\end{array}$ & 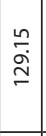 & 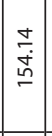 & \begin{tabular}{|l|}
$\infty$ \\
$\infty$ \\
$\infty$ \\
$\tilde{\sigma}$ \\
\end{tabular} & $\begin{array}{l}\hat{L} \\
\dot{\gamma} \\
\end{array}$ & 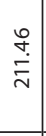 & 1 & 1 & 1 \\
\hline & & 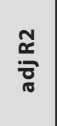 & 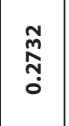 & $\begin{array}{c}\infty \\
\stackrel{\infty}{m} \\
m \\
0\end{array}$ & 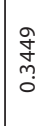 & $\begin{array}{l}0 \\
\stackrel{n}{n} \\
+ \\
0 \\
0\end{array}$ & \begin{tabular}{|l|}
$\stackrel{0}{n}$ \\
$\stackrel{n}{0}$ \\
0
\end{tabular} & $\mid \begin{array}{c}\bar{\sigma} \\
\bar{\sigma} \\
0 \\
\end{array}$ & \begin{tabular}{|l}
0 \\
0 \\
0 \\
$\tilde{m}$ \\
0
\end{tabular} & $\begin{array}{c}\text { N } \\
\stackrel{\infty}{\sim} \\
0 \\
0\end{array}$ & \begin{tabular}{|c|}
$\hat{O}$ \\
$\stackrel{0}{0}$ \\
0
\end{tabular} & $\begin{array}{l}0 \\
\grave{8} \\
0 \\
0\end{array}$ & 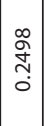 & \begin{tabular}{l}
$\infty$ \\
$\stackrel{0}{0}$ \\
\hdashline
\end{tabular} & $\mid \begin{array}{c}0 \\
\stackrel{o}{+} \\
\stackrel{0}{0}\end{array}$ & 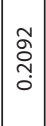 & 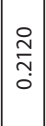 & 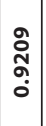 & 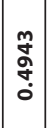 & 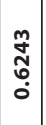 & 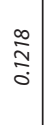 & $\begin{array}{l}\bar{n} \\
0 \\
\vdots \\
0\end{array}$ & 1 & 1 & \begin{tabular}{|c|} 
\\
$\stackrel{0}{0}$ \\
$m$ \\
0 \\
0
\end{tabular} \\
\hline \multirow{4}{*}{ 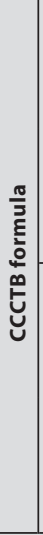 } & \multirow{2}{*}{ 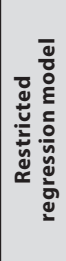 } & 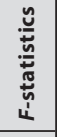 & $\begin{array}{l}\bar{\Gamma} \\
\hat{n} \\
0 \\
\infty \\
\text { N }\end{array}$ & $\begin{array}{l}\hat{N} \\
\stackrel{\sim}{\tilde{\gamma}} \\
\tilde{y}\end{array}$ & 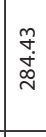 & 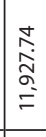 & 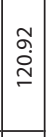 & 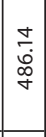 & $\mid$\begin{tabular}{l|}
$\hat{n}$ \\
$\dot{p}$ \\
$m$ \\
$m$ \\
$m$
\end{tabular} & $\begin{array}{l}\bar{n} \\
\frac{5}{4} \\
\overline{6}\end{array}$ & 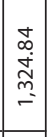 & $\begin{array}{l}\infty \\
\infty \\
\dot{p} \\
\stackrel{v}{\sim}\end{array}$ & 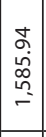 & $\begin{array}{l}\circ \\
\hat{n} \\
n \\
0\end{array}$ & 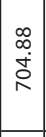 & $\mid$\begin{tabular}{c|}
0 \\
$m$ \\
$i$ \\
$\tilde{m}$ \\
0 \\
$i$ \\
$i$
\end{tabular} & $\begin{array}{l}\infty \\
\underset{\sim}{0} \\
\underset{\sim}{-}\end{array}$ & $\begin{array}{l}\stackrel{\sim}{\sim} \\
\stackrel{\sim}{N}\end{array}$ & $\mid$\begin{tabular}{c}
\multirow{2}{*}{} \\
$\stackrel{2}{\rho}$ \\
$\tilde{m}$
\end{tabular} & 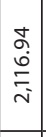 & $\begin{array}{c}\hat{n} \\
\\
\end{array}$ & $\stackrel{m}{\stackrel{m}{\vec{j}}}$ & 1 & 1 & 1 \\
\hline & & 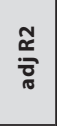 & 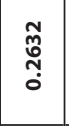 & $\begin{array}{l}\stackrel{n}{\hat{N}} \\
\tilde{m} \\
0\end{array}$ & $\begin{array}{c}\text { I } \\
\text { } \\
\text { d. }\end{array}$ & $\begin{array}{l}\text { o } \\
\text { مे } \\
\text { o. }\end{array}$ & 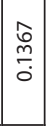 & $\mid \begin{array}{c}\hat{\tilde{O}} \\
\tilde{m} \\
\tilde{0}\end{array}$ & \begin{tabular}{|c|}
0 \\
$\stackrel{0}{n}$ \\
$m$ \\
0 \\
0
\end{tabular} & 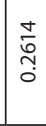 & 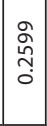 & 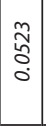 & 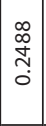 & $\stackrel{\substack{m \\
0}}{0}$ & $\begin{array}{l}\tilde{\alpha} \\
\sigma \\
\\
0\end{array}$ & 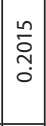 & $\begin{array}{l}t \\
\stackrel{0}{N} \\
0\end{array}$ & 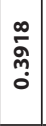 & $\begin{array}{l}n \\
\hat{n} \\
\mathfrak{f} \\
0\end{array}$ & $\begin{array}{l}\hat{n} \\
\hat{n} \\
0\end{array}$ & $\begin{array}{l}\tilde{o} \\
\infty \\
0 \\
0\end{array}$ & $\begin{array}{l}\hat{f} \\
0 \\
\dot{+} \\
\dot{0}\end{array}$ & 1 & 1 & 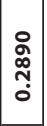 \\
\hline & \multirow{2}{*}{ 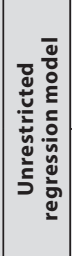 } & 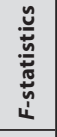 & 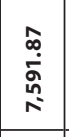 & 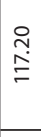 & 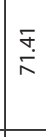 & 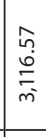 & $\mid \begin{array}{l}m \\
\stackrel{\rho}{i} \\
i\end{array}$ & 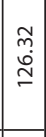 & \begin{tabular}{|c|c}
$\infty$ \\
0 \\
$\infty$ \\
$\infty$ \\
$\infty$
\end{tabular} & $\begin{array}{l}\underset{\infty}{\infty} \\
\underset{\sim}{\infty} \\
\stackrel{\infty}{-}\end{array}$ & \begin{tabular}{|l}
$\infty$ \\
$\stackrel{\infty}{+}$ \\
$\dot{f}$ \\
$m$ \\
$m$
\end{tabular} & $\begin{array}{c}\hat{f} \\
\dot{q}\end{array}$ & $\begin{array}{l}\stackrel{8}{0} \\
\dot{\tilde{j}} \\
\dot{q}\end{array}$ & $\begin{array}{l}\overline{\dot{d}} \\
\underset{\sim}{\Delta}\end{array}$ & $\mid \begin{array}{l}\infty \\
0 \\
\dot{d} \\
\stackrel{1}{\sim}\end{array}$ & $\begin{array}{l}\bar{\infty} \\
\dot{\alpha} \\
\hat{\tilde{n}} \\
\hat{n}\end{array}$ & $\begin{array}{l}\bar{\sigma} \\
\dot{+} \\
\dot{m}\end{array}$ & $\mid \begin{array}{c}\infty \\
\stackrel{\infty}{\dot{m}} \\
\stackrel{m}{m}\end{array}$ & $\begin{array}{l}\stackrel{8}{\circ} \\
\stackrel{\leftrightarrow}{\rightleftharpoons} \\
\end{array}$ & $\mid \begin{array}{l}\bar{N} \\
\stackrel{R}{R}\end{array}$ & $\begin{array}{l}\stackrel{0}{\sim} \\
\underset{m}{m}\end{array}$ & $\begin{array}{l}n \\
0 \\
0 \\
0 \\
-\end{array}$ & 1 & 1 & 1 \\
\hline & & $\underset{\pi}{\stackrel{\Sigma}{z}}$ & $\begin{array}{c}\infty \\
\stackrel{\infty}{\infty} \\
\stackrel{N}{0} \\
0\end{array}$ & 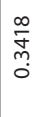 & $\begin{array}{c}\hat{n} \\
\stackrel{p}{p} \\
0\end{array}$ & $\begin{array}{l}0 \\
\stackrel{0}{0} \\
\vdots+ \\
0\end{array}$ & \begin{tabular}{|l|}
$\stackrel{m}{n}$ \\
$\stackrel{n}{0}$ \\
0
\end{tabular} & $\begin{array}{l}0 \\
\stackrel{0}{0} \\
\tilde{m} \\
0\end{array}$ & \begin{tabular}{|c|}
$\mid$ \\
0 \\
0 \\
0 \\
0 \\
0 \\
\end{tabular} & 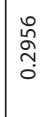 & 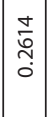 & $\mid \begin{array}{l}0 \\
\stackrel{0}{0} \\
0 \\
0\end{array}$ & $\mid \begin{array}{c}\overline{\tilde{n}} \\
\stackrel{0}{0}\end{array}$ & $\frac{m}{\infty}$ & 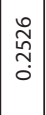 & 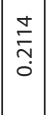 & 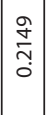 & 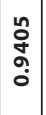 & 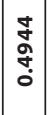 & 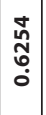 & 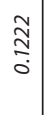 & $\begin{array}{l}\stackrel{0}{0} \\
\dot{+} \\
\dot{0} \\
0\end{array}$ & 1 & 1 & \begin{tabular}{|c|} 
\\
0 \\
$\dot{p}$ \\
$m$ \\
0 \\
0
\end{tabular} \\
\hline & & 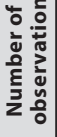 & 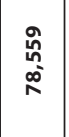 & டి & ్ֶలn & 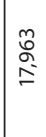 & $\begin{array}{l}\infty \\
\stackrel{\infty}{n}\end{array}$ & 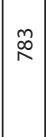 & 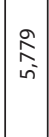 & 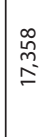 & $\begin{array}{l}\stackrel{R}{r} \\
\hat{n} \\
\dot{n}\end{array}$ & $\begin{array}{l}0 \\
\stackrel{0}{n} \\
i\end{array} \mid$ & 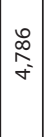 & 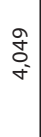 & $\begin{array}{c}0 \\
0 \\
\infty \\
i \\
i\end{array}$ & 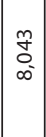 & $\begin{array}{l}\infty \\
\infty \\
\sim \\
\sim\end{array}$ & mे & $\bar{f}$ & $\mid \begin{array}{c}0 \\
o \\
\stackrel{-}{-}\end{array}$ & ช̊ & 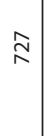 & $\nabla$ & 0 & \\
\hline & & & $=\frac{\breve{u}}{\dot{u}}$ & $\ll$ & $\infty$ & $u$ & 0 & $\boldsymbol{u}$ & 4 & ৩ & $\mathbf{I}$ & - & 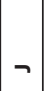 & $x$ & - & $\Sigma$ & $z$ & 0 & 0 & 0 & $\propto$ & $n$ & $\vdash$ & כ & 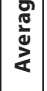 \\
\hline
\end{tabular}


In the average, the portion of explained variability in profit generation by the CCCTB FA amounts to 28.90 per cent, to 28.77 per cent by the US FA and lastly to 26.88 per cent by the Canadian FA. The obtained results are lower in comparison with the explained variability by Krchnivá (2015), who analysed the explanatory power of variety setting of allocation formula on the data sample of Czech individual enterprises. The difference in the obtained results of our analysis are caused by the employing of different data sample, where the relations in group companies may play significant role on the distribution of the profit among them although any tax consolidation scheme is not applied. On the other hand, she (Krchnivá, 2015) also proved the highest explanatory power of the CCCTB FA, as indicated also by the research in this paper. The research revealed that the CCCTB formula is most powerful formula for 8 of 19 considered NACE sectors (there is no evidence for NACE sectors T and $U$ due to the low number of observation). In comparison with the US FA and the Canadian FA, which are most powerful formulas for 4 NACE sectors. The dominance of the CCCTB FA can be explained by the suitability of the incorporation of higher proportion of supply factors (assets and labour) in the allocation formula, whose ability to generate the profit may be influenced by the adjustment of the production process of an individual company, in comparison with the Canadian FA. Further, the dominance of the CCCTB FA may be attributed to the different setting of the labour factor involving the additional measurement, particularly number of employees, which eliminate the differences in wage level in separate economics sectors, relative to both of alternative formulas.

The obtained results about the proportion of the explained variability were further analysed in the context of the distributed share on the overall group tax base to individual economics sectors. The research was performed under the hypothesis that sufficient explanatory power of allocation formula in individual economics sector is indicated by insignificant change in distributed share on the group tax base. The hypothesis was verified separately for each economic sector and for allocation formula which was indicated as the most suitable based on the first research step. Particularly, provided that the change in proportion on overall tax base assigned to individual economics sector was equal to zero or lower of 0.05 per cent the structure of the allocation formula was evaluated to be suitable.

The details about the assigned proportion on the overall group tax base in current system and distributed share on overall tax base by the CCCTB, the US and the Canadian FA can be seen in Table 4. It is necessary to mention, that the research at this step is focussed on the comparative analysis of the aggregated share on the group tax base in separate economic sectors, therefore the research of the distributed proportion among the individual EU Member States we leave for the further research. However, the analysis of the introduction of the CCCTB system from the perspective of the Czech Republic with the employing of data from Amadeus database (namely from its update No. 227, 2013) was previously performed by Nerudová and Solilová (2015), who showed that in situation when the CCCTB system would be introduced in all EU Members States the Czech Republic could gain additional share on overall tax base amounting to 1.22 per cent. 


\begin{tabular}{|c|c|c|c|c|c|c|c|c|c|c|c|c|c|c|c|c|c|c|c|c|c|}
\hline 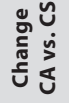 & $\begin{array}{l}\text { oें } \\
\text { o. }\end{array}$ & $\begin{array}{l}\stackrel{\circ}{0} \\
\text { Oे }\end{array}$ & $\stackrel{\stackrel{\circ}{m}}{\stackrel{i}{i}}$ & 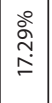 & $\begin{array}{l}\text { oे } \\
\text { ì } \\
\text { ì }\end{array}$ & \begin{tabular}{l|}
$\stackrel{0}{\circ}$ \\
$\dot{0}$ \\
$\dot{0}$ \\
$\dot{0}$
\end{tabular} & $\stackrel{\stackrel{\circ}{m}}{\circ}$ & $\begin{array}{c}\stackrel{0}{0} \\
\infty \\
0 \\
0\end{array}$ & $\begin{array}{c}\circ \\
\stackrel{\circ}{\infty} \\
\dot{0} \\
\dot{0}\end{array}$ & $\begin{array}{l}\stackrel{\circ}{\circ} \\
\stackrel{2}{0} \\
\dot{0}\end{array}$ & $\begin{array}{c}\stackrel{\circ}{\circ} \\
\stackrel{0}{0}\end{array}$ & $\begin{array}{l}\stackrel{0}{ } \\
\infty \\
\leftrightarrow \\
\infty \\
1\end{array}$ & $\begin{array}{l}\stackrel{\circ}{0} \\
\dot{0} \\
0\end{array}$ & $\begin{array}{c}\stackrel{\circ}{\stackrel{0}{m}} \\
\stackrel{T}{T}\end{array}$ & 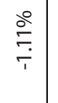 & $\begin{array}{l}\circ \\
\stackrel{0}{0} \\
\dot{0}\end{array}$ & $\begin{array}{l}\text { Oें } \\
\circ \\
\dot{0}\end{array}$ & $\begin{array}{l}\circ \\
\stackrel{0}{0} \\
\dot{0}\end{array}$ & $\frac{\circ}{\circ}$ & $\begin{array}{l}\text { ○ें } \\
\text { ڤે } \\
\text { i. }\end{array}$ & $\begin{array}{l}\text { ò } \\
\text { ò } \\
\dot{0}\end{array}$ \\
\hline 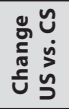 & 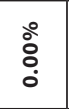 & $\frac{\circ}{\circ}$ & $\frac{\stackrel{\circ}{\circ}}{\dot{m}}$ & 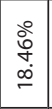 & $\begin{array}{c}\stackrel{0}{0} \\
\stackrel{0}{i} \\
i\end{array}$ & 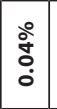 & 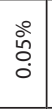 & 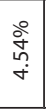 & \begin{tabular}{|c|}
$\stackrel{\circ}{+}$ \\
$\stackrel{0}{0}$ \\
0
\end{tabular} & $\begin{array}{l}\text { 吕 } \\
\hat{0} \\
0\end{array}$ & 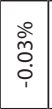 & $\begin{array}{l}\stackrel{\circ}{\circ} \\
\dot{i n} \\
\infty \\
1\end{array}$ & $\mid \begin{array}{l}0 \\
\vdots \\
0 \\
0\end{array}$ & 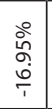 & 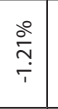 & ஃें & $\begin{array}{l}\text { ¿ें } \\
\dot{0} \\
\dot{0}\end{array}$ & 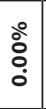 & 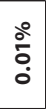 & $\begin{array}{l}\text { ڤ̊ } \\
\hat{0} \\
0 \\
0\end{array}$ & : \\
\hline 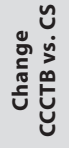 & $\begin{array}{l}\circ \\
\text { ○ें } \\
0\end{array}$ & 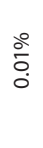 & 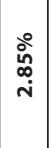 & \begin{tabular}{|c|}
$\stackrel{0}{0}$ \\
$\hat{\sigma}$ \\
$\infty$ \\
$\infty$
\end{tabular} & $\begin{array}{c}\stackrel{0}{0} \\
\stackrel{m}{0} \\
i\end{array}$ & $\begin{array}{l}\circ \\
\stackrel{0}{0} \\
\dot{0} \\
\dot{0}\end{array}$ & $\begin{array}{l}\stackrel{\circ}{\circ} \\
\dot{0} \\
\dot{0}\end{array}$ & $\begin{array}{l}\stackrel{\circ}{\grave{8}} \\
\stackrel{+}{+}\end{array}$ & 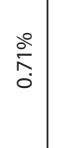 & 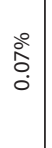 & 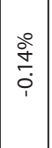 & $\begin{array}{l}\stackrel{\circ}{0} \\
0 \\
\infty \\
\infty \\
1\end{array}$ & $\mid \begin{array}{c}0 \\
\vdots \\
0 \\
0\end{array}$ & $\begin{array}{l}\stackrel{0}{0} \\
\hat{\sigma} \\
\stackrel{0}{\circ} \\
i\end{array}$ & $\stackrel{\stackrel{\circ}{\circ}}{\div}$ & $\begin{array}{l}\circ \\
\stackrel{\circ}{0} \\
\dot{0}\end{array}$ & $\begin{array}{l}\circ \\
\circ \\
0 \\
0\end{array}$ & $\begin{array}{l}\circ \\
\text { ¿ें } \\
0\end{array}$ & $\begin{array}{l}\stackrel{0}{0} \\
\vdots \\
0\end{array}$ & $\begin{array}{l}0 \\
\grave{0} \\
0 \\
0 \\
1\end{array}$ & $\begin{array}{l}\text { @ें } \\
\vdots \\
0\end{array}$ \\
\hline$\frac{\pi}{5}$ & $\begin{array}{l}\circ \\
\vdots \\
\dot{0}\end{array}$ & $\begin{array}{l}\stackrel{\circ}{0} \\
\stackrel{0}{0} \\
\end{array}$ & $\begin{array}{l}\stackrel{0}{0} \\
\hat{1} \\
\dot{0}\end{array}$ & \begin{tabular}{|c|}
0 \\
0 \\
0 \\
$\dot{q}$ \\
\end{tabular} & $\begin{array}{l}\text { ○ें } \\
0 \\
0 \\
0 \\
0\end{array}$ & $\begin{array}{l}0 \\
0 \\
0 \\
0 \\
0\end{array}$ & 宫 & $\begin{array}{c}\stackrel{\circ}{\circ} \\
\stackrel{5}{=} \\
=\end{array}$ & 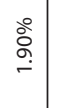 & 今ั & \begin{tabular}{|l|}
80 \\
6 \\
6 \\
$\dot{n}$
\end{tabular} & 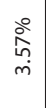 & $\begin{array}{c}\stackrel{0}{0} \\
\frac{m}{m} \\
0\end{array}$ & $\stackrel{\stackrel{\circ}{\circ}}{\stackrel{0}{\stackrel{n}{\sim}}}$ & 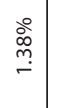 & ○ें & $\begin{array}{l}\text { ¿ें } \\
\vdots \\
0\end{array}$ & $\begin{array}{l}\text { :ें } \\
\text { :े } \\
\dot{0}\end{array}$ & $\begin{array}{l}\stackrel{\circ}{0} \\
\vdots \\
0\end{array}$ & ò & $\begin{array}{l}\text { वें } \\
\text { ¿े }\end{array}$ \\
\hline 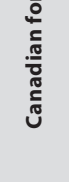 & 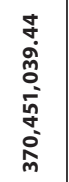 & $\begin{array}{l}0 \\
2 \\
0 \\
\hat{0} \\
\hat{2} \\
0 \\
0\end{array}$ & 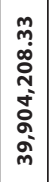 & 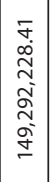 & $\begin{array}{l}\bar{\sigma} \\
\infty \\
\bar{\sigma} \\
\dot{\sigma} \\
\frac{m}{m} \\
\bar{m}\end{array}$ & 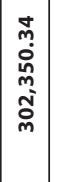 & 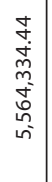 & 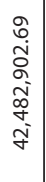 & 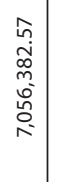 & \begin{tabular}{l}
$\stackrel{0}{ }$ \\
$\dot{0}$ \\
$\infty$ \\
$\infty$ \\
$\infty$ \\
0 \\
0 \\
0 \\
\hdashline
\end{tabular} & 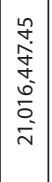 & 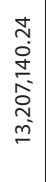 & 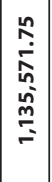 & 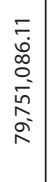 & $\begin{array}{l}0 \\
\infty \\
0 \\
0 \\
0 \\
\infty \\
\infty \\
\stackrel{0}{\sigma} \\
i n\end{array}$ & 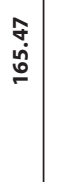 & $\begin{array}{l}\stackrel{0}{0} \\
\dot{m} \\
\infty \\
\stackrel{0}{+} \\
N\end{array}$ & 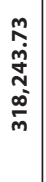 & $\begin{array}{l}0 \\
0 \\
\dot{0} \\
0 \\
\circ \\
\dot{+}\end{array}$ & $\begin{array}{l}m \\
m \\
\infty \\
\infty \\
\infty \\
\stackrel{0}{0} \\
\tilde{j} \\
m\end{array}$ & $\begin{array}{l}8 \\
0 \\
\vdots \\
0 \\
0 \\
0\end{array}$ \\
\hline & $\begin{array}{l}\circ \\
\circ \\
\circ \\
\dot{0}\end{array}$ & $\stackrel{\circ}{\stackrel{0}{\circ}}$ & $\begin{array}{l}\stackrel{\circ}{\circ} \\
\stackrel{\infty}{=} \\
=\end{array}$ & \begin{tabular}{|c|}
$\stackrel{\circ}{\grave{\gamma}}$ \\
$\dot{f}$ \\
$\dot{\sigma}$
\end{tabular} & $\begin{array}{l}\stackrel{\circ}{ } \\
\stackrel{\circ}{\circ} \\
0\end{array}$ & $\begin{array}{l}\text { ò } \\
\circ \\
0 \\
\dot{0}\end{array}$ & 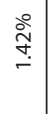 & $\frac{\circ}{\stackrel{0}{\dagger}}$ & 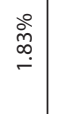 & 今े & $\begin{array}{l}\stackrel{\circ}{\circ} \\
\text { ò } \\
\text { ì }\end{array}$ & $\begin{array}{l}\stackrel{\circ}{+} \\
\dot{\mathrm{m}}\end{array}$ & $\begin{array}{c}\stackrel{\circ}{\circ} \\
\stackrel{m}{0} \\
0\end{array}$ & $\begin{array}{l}\stackrel{\circ}{\circ} \\
\dot{\sim} \\
\dot{\sim}\end{array}$ & $\stackrel{\stackrel{\circ}{\circ}}{\stackrel{\infty}{+}}$ & $\begin{array}{l}\stackrel{\circ}{\circ} \\
\stackrel{0}{0}\end{array}$ & $\begin{array}{l}\text { oे } \\
\dot{0} \\
\dot{0}\end{array}$ & $\begin{array}{l}\stackrel{0}{\circ} \\
\stackrel{0}{0} \\
\dot{0}\end{array}$ & $\frac{\circ}{0}$ & $\begin{array}{l}\text { ஓे } \\
0 \\
0 \\
0\end{array}$ & $\begin{array}{l}\stackrel{\circ}{\circ} \\
\dot{0}\end{array}$ \\
\hline$\frac{\vec{\varepsilon}}{\frac{b}{n}}$ & 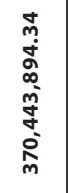 & $\begin{array}{l}\overline{0} \\
\dot{0} \\
0 \\
\hat{0} \\
0 \\
0\end{array}$ & 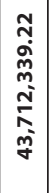 & 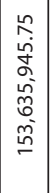 & 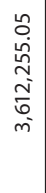 & $\begin{array}{c}\mathfrak{N} \\
\tilde{m} \\
\tilde{m} \\
\stackrel{m}{2} \\
\text { స్ }\end{array}$ & 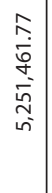 & $\begin{array}{l}\tilde{m} \\
\tilde{n} \\
\alpha \\
\vdots \\
\vdots \\
\infty \\
\tilde{m} \\
m\end{array}$ & \begin{tabular}{|c|}
$\infty$ \\
0 \\
0 \\
0 \\
0 \\
$\infty$ \\
$\infty$ \\
0 \\
0 \\
0
\end{tabular} & $\begin{array}{l}\text { N } \\
\hat{0} \\
0 \\
\infty \\
\infty \\
0 \\
0 \\
=\end{array}$ & 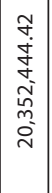 & $\begin{array}{l}m \\
m \\
o \\
0 \\
0 \\
o \\
\dot{f} \\
m \\
\end{array}$ & 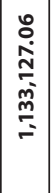 & 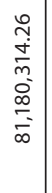 & 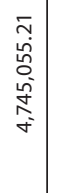 & $\begin{array}{c}\stackrel{m}{m} \\
\stackrel{\leftrightarrow}{\grave{N}}\end{array}$ & $\begin{array}{l}\mathcal{q} \\
\tilde{n} \\
\hat{n} \\
\tilde{n}\end{array}$ & 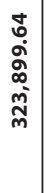 & 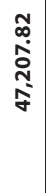 & $\begin{array}{l}\stackrel{0}{2} \\
\stackrel{n}{n} \\
i n \\
\sim \\
\\
\end{array}$ & 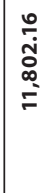 \\
\hline$\frac{\pi}{3}$ & $\begin{array}{l}\circ \\
0 \\
\circ \\
0\end{array}$ & $\stackrel{\circ}{\stackrel{0}{\circ}}$ & $\begin{array}{l}\stackrel{\circ}{\circ} \\
\stackrel{n}{=} \\
=\end{array}$ & \begin{tabular}{|c|}
$\stackrel{\circ}{\circ}$ \\
$\stackrel{0}{\dot{\sigma}}$ \\
$\dot{\sigma}$
\end{tabular} & $\begin{array}{l}\stackrel{\circ}{\circ} \\
\circ \\
\circ\end{array}$ & $\begin{array}{l}\text { ò } \\
\circ \\
0 \\
\dot{0}\end{array}$ & 号 & $\begin{array}{c}\stackrel{0}{0} \\
\hat{m} \\
\alpha\end{array}$ & $\begin{array}{l}\stackrel{\circ}{\circ} \\
\stackrel{\infty}{+} \\
-\end{array}$ & ণัें & \begin{tabular}{|c|}
$\stackrel{0}{2}$ \\
on \\
in
\end{tabular} & $\begin{array}{l}\stackrel{\circ}{0} \\
\stackrel{0}{0} \\
\dot{m}\end{array}$ & 总 & $\begin{array}{l}\stackrel{\circ}{\circ} \\
\stackrel{\leftrightarrow}{\sim} \\
\dot{\sim}\end{array}$ & 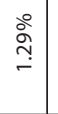 & $\begin{array}{l}\stackrel{\circ}{\circ} \\
\stackrel{0}{0}\end{array}$ & $\begin{array}{l}\stackrel{\circ}{\circ} \\
\dot{0}\end{array}$ & $\begin{array}{l}\stackrel{0}{\circ} \\
\stackrel{0}{0} \\
\dot{0}\end{array}$ & $\begin{array}{l}\stackrel{\circ}{\circ} \\
\dot{0} \\
\dot{0}\end{array}$ & $\begin{array}{l}\text { ஓे } \\
0 \\
0 \\
0\end{array}$ & $\begin{array}{l}\text { :े } \\
\text { ¿े }\end{array}$ \\
\hline 竎 & 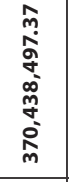 & 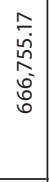 & 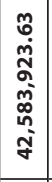 & 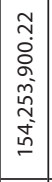 & 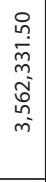 & 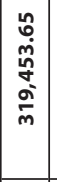 & 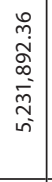 & 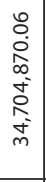 & 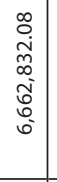 & 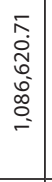 & 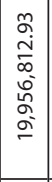 & 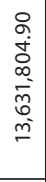 & 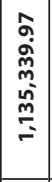 & 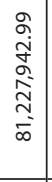 & 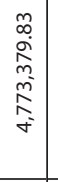 & 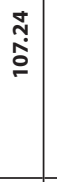 & $\begin{array}{l}\hat{i n} \\
\dot{j} \\
\stackrel{g}{\alpha} \\
\alpha\end{array}$ & 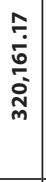 & 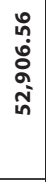 & $\begin{array}{l}\tilde{\alpha} \\
\hat{\tilde{n}} \\
\hat{\alpha} \\
\text { ป̀ }\end{array}$ & 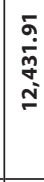 \\
\hline$\underline{\Xi}$ & $\begin{array}{l}\circ \\
\stackrel{0}{0} \\
\dot{0}\end{array}$ & 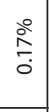 & 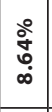 & $\mid \begin{array}{l}\stackrel{\circ}{0} \\
\dot{0} \\
\ddot{n}\end{array}$ & $\stackrel{\text { ڤ̊ }}{\stackrel{一}{-}}$ & 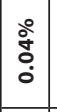 & $\stackrel{\stackrel{\circ}{\hat{\rho}}}{\stackrel{m}{-}}$ & $\begin{array}{l}\stackrel{\circ}{0} \\
\dot{0} \\
\dot{+}\end{array}$ & 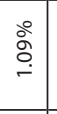 & $\stackrel{\text { ஸें }}{\underset{0}{0}}$ & 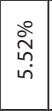 & 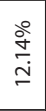 & 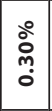 & $\begin{array}{l}\stackrel{0}{0} \\
\infty \\
\infty \\
\infty \\
m\end{array}$ & ஓ̊̊ & ڤ̊ํㅇ & $\begin{array}{l}\text { ○ें } \\
\dot{0}\end{array}$ & 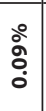 & $\begin{array}{l}\circ \\
\stackrel{0}{0} \\
\dot{0}\end{array}$ & $\frac{\stackrel{0}{0}}{0}$ & $\begin{array}{l}\stackrel{\circ}{\circ} \\
\vdots \\
0\end{array}$ \\
\hline 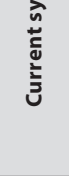 & 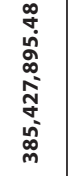 & 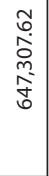 & 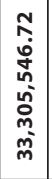 & 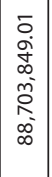 & $\begin{array}{l}\bar{F} \\
\bar{a} \\
0 \\
\infty \\
\infty \\
o \\
\sigma \\
+\end{array}$ & $\begin{array}{c}\mathfrak{N} \\
\dot{j} \\
\dot{f} \\
\infty \\
\stackrel{0}{0} \\
\end{array}$ & 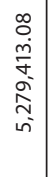 & 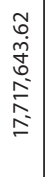 & 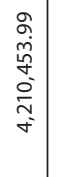 & $\begin{array}{l}0 \\
0 \\
0 \\
0 \\
o \\
o ̂ \\
\infty \\
\infty\end{array}$ & 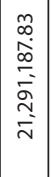 & 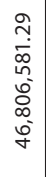 & 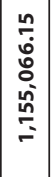 & $\begin{array}{l}\infty \\
\infty \\
\hat{\omega} \\
\sim \\
0 \\
\infty \\
0 \\
0 \\
\sigma \\
\sigma\end{array}$ & $\begin{array}{l}\infty \\
\infty \\
\stackrel{0}{0} \\
\stackrel{0}{0} \\
\infty \\
\infty \\
\sim \\
\omega \\
\sigma\end{array}$ & 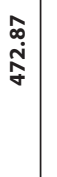 & $\begin{array}{l}\infty \\
\stackrel{\infty}{\infty} \\
\infty \\
\stackrel{i}{N}\end{array}$ & 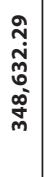 & $\begin{array}{l}n \\
\infty \\
\infty \\
+ \\
0 \\
0\end{array}$ & 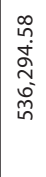 & 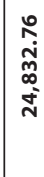 \\
\hline 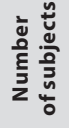 & $\begin{array}{l}\stackrel{+}{+} \\
\stackrel{5}{=}\end{array}$ & $\stackrel{\infty}{=}$ & $\tilde{g}$ & $\left|\begin{array}{c}\infty \\
\infty \\
\sim \\
\sim \\
N\end{array}\right|$ & $\stackrel{P}{m}$ & mे & $\overline{\tilde{n}}$ & 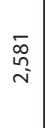 & $\frac{\pi}{d}$ & I্ & in & $\stackrel{\varkappa}{\wedge}$ & $\hat{\infty}$ & 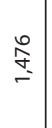 & $\overline{6}$ & $m$ & ก & $\stackrel{\infty}{\bullet}$ & $\mathcal{F}$ & $\bullet$ & - \\
\hline & 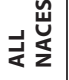 & $\ll$ & $\infty$ & $u$ & 0 & \begin{tabular}{|l|} 
\\
\end{tabular} & 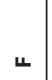 & $\checkmark$ & $I$ & - & 7 & $\mathbf{x}$ & -1 & $\Sigma$ & $z$ & 0 & $a$ & 0 & $\approx$ & $n$ & $\vdash$ \\
\hline
\end{tabular}


From the Table 4 it can be observed that the highest proportion in overall tax base of studied data sample is assigned in the current system of separate accounting to NACE sectors M (38.86 per cent), C (23.01 per cent) and K (12.14 per cent). If the CCCTB allocation formula or US and Canadian formula will be applied for the distribution of the overall tax base, the profit share assigned to the individual economic sectors significantly differs. This difference is attributable to the application of the allocation formula, which shall secure that the profit will be taxed where is generated.

As can be clearly seen from the Table 4, the overall tax base is by EUR 14,989,398.11 ths (i.e. by 3.89) lower under the CCCTB system than in the current system. The decrease of the overall group tax base is caused by the application of lossoffsetting mechanism, which secures that only net profit of a group company is taxed. It has to be mentioned that only the different setting of the CCCTB formula, particularly its substitution by the US or the Canadian FA, was analysed in the paper, the other condition of the CCCTB system stayed unchanged. Thus, the analysis of the Canadian FA is applied with the possible loss-offsetting mechanism, although the tax consolidation is not permitted in Canada.

No change in the distributed proportion in overall group tax base was indicated for NACE sectors O, P, Q and R. In the light of the first research step, for NACE sectors $\mathrm{O}$ and $\mathrm{P}$ the highest explanatory power of the US FA was obtained. For NACE sector $\mathrm{Q}$ was indicated as the most suitable formula the Canadian one and for NACE sector R the CCCTB FA. Small change up to 0.05 per cent of assigned proportion to individual economic sector was obtained for NACE sectors A, E, F and L, for which the CCCTB FA seems to be the most suitable. As can be further seen, the results gained for NACE sectors $\mathrm{M}$ and $\mathrm{S}$ are not in the line with the evidence about the explanatory power amounting in average to 40.00 per cent. NACE sector M suffers a loss of the assigned proportion on the group tax base almost by 17.00 per cent, which denotes the insufficient explanatory power of any of the considered formula for this sector. The results are justifiable by the special characteristics of professional, scientific and technical activities, where the generated profit is probably more influenced by the human factor and technical facilities, which are represented by assets and labour factor in the considered FA than by the volume of demand described by sales factor. Similar decrease in the assigned proportion on the group tax base is experienced by NACE sector K, which suggests the unsatisfactory setting of any of considered formulas. This result underlays the necessity for the special definition of the formula for finance and insurance activities. The largest NACE sector $\mathrm{C}$ in the considered data sample achieves additional share on overall tax base of almost 19.00 per cent under the US and the CCCTB FA, which indicates the sufficient explanatory of these formulas.

The highest difference in the distributed share on overall tax base among the analysed formulas was indicated for NACE sector G, where under the Canadian FA higher proportion of demand side factors is considered. A controversial result was gained for NACE sector J, whereas under the CCCTB FA a decrease of 0.14 per cent of assigned proportion was indicated, in case of the Canadian FA an increase of 0.15 per cent was 
reached. In line with the characteristics of Information and Communication activities (NACE sector J), the role of assets factor is questionable and the demand sales factor may play more important role in the distribution of the profit for this sector.

With respect to the gained results from both analysis, we may conclude that the CCCTB formula have the most explanatory power in the highest number of NACE sectors, which provides and evidence of the eligible inclusion of both input and output formula factors in the allocation mechanism. No or very small change in the distributed share on the group tax base under all considered formula indicates the suitable incorporation of sales, assets and payroll factors into the allocation formula for 9 out of 19 examined economic sectors. However, where the decline in the assigned proportion was identified, the adjustment of the definition of formula factors is suggested by the analysis performed in the paper. These are represented by NACE sectors $\mathrm{K}, \mathrm{M}$ and $\mathrm{D}$, where an average 15.85 per cent explanatory power of the CCCTB allocation formula was indicated.

\section{Conclusion}

The aim of the paper was to verify the suitability of tax sharing system incorporated in the CCCTB for the distribution of the group tax base on the example of the Czech Republic and to research whether the CCCTB system would reflect the generation of the profit in each jurisdiction, where a member of the group company is seated. Further, the aim of the paper was to research the evidence of the suitability of the CCCTB FA from the perspective of different economic sectors defined by the NACE codes. The data of the eligible group companies for the CCCTB system with the link to the Czech Republic were employed in the paper. It means, only the data of group companies with the parent company situated in the Czech Republic and owning an eligible subsidiary resident elsewhere in the EU and of the group companies with the parent company resident elsewhere in the EU owning an eligible subsidiary seated in the Czech Republic. Our analysis was focussed on the evaluation of the allocation formula and the analysis of the distribution of the group tax base among the EU countries and the budgetary impact of the introduction of the CCCTB system we leave for further research.

The proposed CCCTB FA was compared with the allocation formulas designed for the distribution of corporate income tax in the United States of America and Canada.

The research was performed in the two single steps. Firstly, the explanatory power of examined formulas to indicate the process of generation of the profit were analysed by the unrestricted and restricted multiple regression models. The evaluation of the explanatory power was based on the comparison of the adjusted coefficient of determination giving the information about the proportion of explained variability of the proposed regression model. Based on the results, the CCCTB allocation formula is able to explain 26.32 per cent of the variability (see Table 3 ). The similar result was gained for the US allocation formula and the explanatory power evidence for Canadian allocation formula was of 1 per cent lower.

The results for the CCCTB allocation formula are lower by 2 per cent in comparison with the results of Roggeman et al. (2012), who analysed the explanatory power of the formula 
for the companies operating only in manufacturing and service sectors. However, in accordance with study of Krchnivá (2015), the CCCTB allocation formula seems to be the best performing formula besides other researched formulas. This conclusion is also confirmed by the results of the second research step, where the comparison of the distributed share in the overall tax base in the current system and in the CCCTB system with three possible arrangements of formula was performed. The calculation of the assigned share in the overall tax base was completed for individual economic sectors and further compared with respect to the change in the distributed proportion in overall tax base. The evaluation of the obtained outcomes was executed under the hypothesis that the formula factors are able to explain the sufficient proportion of the variability in the profit provided that the change in the shared proportion on overall tax base is zero or very small (that is lower of 0.05 per cent). These results were indicated for 9 of 19 NACE sectors.

The outcomes for the CCCTB and the US allocation formulas are very similar, while the results for the Canadian formula are slightly different. This is caused mainly by the incorporation of assets and payroll formula factor. The paper also proposes the different design of the formula factors for NACE sectors K, M and D. Regardless that based on the analysis performed in the paper the CCCTB formula factors are justifiable as profit generation factors, the consideration of volume of their impact on the generation of the profit is the question for the next research.

\section{References}

Agundez-Garcia, A. (2006). The Delineation and Apportionment of an EU Consolidated Tax Base for Multi-Jurisdictional Corporate Income Taxation: a Review of Issues and Options. Working Paper (European Commission Taxation Papers). [Retrieved: 2016-26-2] Available at: http://ec.europa.eu/taxation_customs/resources/documents/taxation/gen_info/ economic_analysis/tax_papers/taxation_paper_09_complete_en.pdf

Anand, B., Sansing, R. (2000). The Weighting Game: Formula Apportionment as an Instrument of Public Policy. National Tax Journal, 53(2), 183-199, https://doi.org/10.17310/ ntj.2000.2.01, [Retrieved: 2016-26-2] Available at: http://www.ntanet.org/NTJ/53/2/ ntj-v53n02p183-200-weighting-game-formula-apportionment.pdf

Cline, R., Neubig, T. et al. (2010). Study on the Economic and Budgetary Impact of the Introduction of a Common Consolidated Corporate Tax Base in the European Union. Commissioned by the Irish Department of Finance. [Retrieved: 2016-26-2] Available at: http://taxpolicy.gov.ie/wp-content/uploads/2011/06/EY-Report-CCCTB-forCommissioner-Semeta-4-Jan-2011.pdf

Eggert, W., Schjelderup, G. (2003). Symmetric Tax Competition under Formula Apportionment. Journal of Public Economic Theory, 5(2), 439-446, https://doi.org/10.1111/1467-9779.00141

European Commission. (2011). Proposal for A Council Directive on a Common Consolidated Corporate Tax Base (CCCTB). Brussels. Com (2011) 121/4. 2011/0058 (CNS).

Gerard, M., Weiner, J. M. (2003). Cross-Border Loss Offset and Formulary Apportionment: How Do They Affect Multijurisdictional Firm Investment Spending and Interjurisdictional Tax Competition? CESifo. Working Paper No. 1004. [Retrieved: 2016-26-2] Available at: https://www.uclouvain.be/cps/ucl/doc/iag/documents/WP_97_Gerard.pdf 
Gordon, R., Wilson, J. (1986). An Examination of Multijurisdictional Corporate Income Taxation under Formula Apportionment. Econometrica, 54(6), 1357-1373, https://doi.org/10.2307/1914303

Kolmar, M., Wagener, A. (2007). The Competiton with Formula Apportionment: The Interaction between Tax Base and Sharing Mechanism. CESifo. Working Paper No. 2097. [Retrieved: 2016-26-2] Available at: https://www.cesifo-group.de/portal/pls/ portal/!PORTAL.wwpob_page.show?_docname=947932.PDF

Krchnivá, K. (2015). The Czech Evidence for the Explanatory Power of Formula Factors on Profitability. Ekonomická revue - Central European Review of Economic, 18, 131-138.

Krchnivá, K., Nerudová, D. (2015). The Influence of Allocation Formula on Generation of Profit in Different Economy Sectors. Acta Universitatis Agriculturae et Silviculturae Mendelianae Brunensis, 63(6), 1961-1967, https://doi.org/10.11118/201563061961

McLure, C. E. (1980). The State Corporate Income Tax: Lambs in Wolves' Clothing, in Aaron, A. J., Boskin, M. J., eds., The Economics of Taxation. Washington, DC: The Brookings Institution, 327-336.

Nielsen, S. B., Raimondos-Møller, P., Schjelderup, G. (2001). Tax Spillovers under Separate Accounting and Formula Apportionment. Institute of Economics, University of Copenhagen. EPRU Working Paper No. 2001-07. [Retrieved: 2016-26-2] Available at: http://openarchive.cbs.dk/bitstream/handle/10398/7645/web-blaa-2001-07. pdf? sequence $=1$

Nerudová, D., Solilová V. (2014). Missing Data and its Impact on the CCCTB Determination. 17th International Conference Enterprise and Competitive Environment 2014. Book Series: Procedia Economics and Finance. 12, 462-471.

Nerudová, D., Solilová V. (2015). The Impact of the CCCTB Introduction on the Distribution of the Group Tax Bases across the EU: The Study for the Czech Republic. Prague Economic Papers, 24(6), https://doi.org/10.18267/j.pep.514

Nerudová, D., Solilová, V., Bohušová, H., Svoboda, P. (2015). Dopady zavedení CCCTB na rozpočet Ceske republiky. (The budgetary impact of the introduction of the CCCTB in the Czech Republic). Prague: Wolters Kluwer, a. S., ISBN 978-80-7478-954-0.

Pethig, R., Wagener, A. (2003). Profit Tax Competition and Formula Apportionment. CESifo. Working Paper No. 1011. University of Munich. [Retrieved: 2016-26-2] Available at: $\mathrm{ftp}$ //ftp.repec.org/opt/ReDIF/RePEc/sie/papers/106-03.pdf

Riedel, N., Runkel, M. (2006). Company Tax Reform with a Water's Edge. Department of Economics, University of Munich. [Retrieved: 2016-26-2] Available at: http://ftp.zew.de/ pub/zew-docs/sw_2006/papers/riedel_zew_summerworkshop2006.pdf

Roggeman, A., Varleyen, I., Van Cauwenberge P., Coppens C. (2012). An Empirical Investigation into the Design of an EU Apportionment Formula Related to Profit Generating Factors. Transformations in Business \& Economics, Vol. 11, No 3(27), 36-56. ISSN 1648-4460.

Runkel, M., Schjelderup, G. (2007). The Choice of Apportionment Factors under Formula Apportionment. CESifo. Working Paper No. 2072. [Retrieved: 2016-26-2] Available at: http://papers.ssrn.com/sol3/papers.cfm?abstract_id=1005578

Tan, J. H. D. (2010). Unitary Formulary Apportionment as a Solution to the Conundrum of Source. [Retrieved: 2016-26-2] Available at: http://www.jmls.edu/academics/taxeb/pdf/ Faherty_1.pdf 
U.S. Congress, House Committee on the Judiciary, State Taxation of Interstate Commerce: Report of the Special Subcommittee on State Taxation of Interstate Commerce (The Willis Report), 4 (1, 2): 88th Cong., 2d Sess., June 15, 1964, H. Rep. 1480; Vol. 3 89th Cong., 1st Sess., June 30, 1965, H. Rept. 565; Vol. 4: 89th Cong., 1st Sess., Sept. 2, 1965, H. Rept. 952

Weiner, J. M. (2005). Formulary Apportionment and Group Taxation in the European Union: Insights from the United States and Canada. Working Paper No. 8/2005. ISBN 92-894-6090-3. [Retrieved: 2016-26-2] Available at: http://ec.europa.eu/taxation_customs/resources/ documents/taxation/gen_info/economic_analysis/tax_papers/2004_2073_en_web_final_ version.pdf

Weiner, J. M. (1999). Using the Experience in the U.S. States to Evaluate Issues in Implementing Formula Apportionment at the International Level. OTA Paper 83. [Retrieved: 2016-26-2] Available at: https://www.treasury.gov/resource-center/tax-policy/tax-analysis/ Documents/OTA-WP-83.pdf 